\title{
Proanthocyanidins and Related Compounds: Antileishmanial Activity and Modulatory Effects on Nitric Oxide and Tumor Necrosis Factor- $\alpha$-Release in the Murine Macrophage-Like Cell Line RAW 264.7
}

\author{
Herbert Kolodziej, ${ }^{a}$ Oliver Kayser, ${ }^{b}$ Albrecht F. Kiderlen, ${ }^{c}$ Hideyuki Ito, ${ }^{d}$ Tsutomu Hatano, ${ }^{d}$ \\ Takashi YoshIDA, ${ }^{*}, d$ and Lai Yeap FoO $^{e}$ \\ Institute of Pharmacy, Pharmaceutical Biology, Freie Universität Berlin, ${ }^{a}$ Königin-Luise-Str. $2+4$, D-14195 Berlin, \\ Germany, Institute of Pharmacy, Pharmaceutical Technology, Biopharmacy and Biotechnology, Freie Universität Berlin, ${ }^{b}$ \\ Kelchstraße 31, D-12169 Berlin, Germany, Robert Koch-Institut, Department of Infectious Diseases, ${ }^{c}$ Nordufer 20, D- \\ 13353 Berlin, Germany, Faculty of Pharmaceutical Sciences, Okayama University, ${ }^{d}$ Tsushima, Okayama 700-8530, Japan, \\ and New Zealand Institute for Industrial Research, ${ }^{e}$ Gracefield Road, P.O. Box 31-310, Lower Hutt, New Zealand. \\ Received February 16, 2001; accepted June 18, 2001
}

\begin{abstract}
A series of 17 proanthocyanidins and structurally related compounds was tested for activity against Leishmania donovani amastigotes and promastigotes in vitro. Most of the polyphenols significantly inhibited the intracellular survival of $L$. donovani amastigotes $\left(\mathrm{EC}_{50} 0.8-10.6 \mathrm{~nm}\right)$ when compared with the antileishmanial drug Pentostam $^{\circledR}\left(\mathrm{EC}_{50} 10.6 \mathrm{nM}\right)$, but all were inactive against the extracellular form $\left(\mathrm{EC}_{50} 7.8\right.$ to $\left.>86 \mathrm{~nm}\right)$. Noteworthy is that all compounds exhibited only moderate or no cytotoxicity against the murine host cells $\left(\mathrm{EC}_{50} 7.8\right.$ to $>56 \mathrm{nM} ;>25 \mu \mathrm{g} / \mathrm{ml})$. These polyphenols were further evaluated for immunomodulatory effects on macrophage functions, including release of nitric oxide (NO), tumor necrosis factor- $\alpha$ (TNF) and interferon (IFN)-like properties using several functional assays. The results showed that all compounds induced murine RAW 264.7 cells only moderately to release NO $(7-26 \mu \mathrm{M})$ relative to the reference stimulus IFN- $\gamma / \mathrm{LPS}(119 \mu \mathrm{M})$. The TNF-inducing potential of the polyphenols producing $50 \%$ lysis in murine $\mathrm{L} 929$ cells ranged from absent to $138 \mathrm{U} / \mathrm{ml}$ at the host cell subtoxic concentration of $50 \mu \mathrm{g} / \mathrm{ml}$. The highest TNF-inducing activity was associated with those flavan-3-ols with galloyl groups $(98-127 \mathrm{U} / \mathrm{ml})$. For proanthocyanidins, it appeared that an increase in the flavanyl chain length did not enhance the induction of TNF-release $(32-86 \mathrm{U} / \mathrm{ml}$ and below detection limits for oligomers and polymers, respectively). With interferon-like activities, phylloflavan and a prodelphinidin polymer showed appreciable cytoprotective effects, as reflected by the inhibition of the cytopathic effect of encephalomyocarditis virus on $\mathrm{L929}$ fibroblast cells (38 and $36 \mathrm{U} / \mathrm{ml}$, respectively). All remaining compounds displayed only negligible or moderate protective effects at subtoxic concentrations up to $25 \mu \mathrm{g} / \mathrm{ml}(<5$ to $12 \mathrm{U} / \mathrm{ml})$. These results indicate that proanthocyanidins and related compounds have favorable antileishmanial activity in vitro and might be considered as beneficial immunological response modifiers provided there are no bioavailability problems.
\end{abstract} factor

Key words proanthocyanidin; Leishmania donovani; antileishmanial activity; immunomodulation; nitric oxide; tumor necrosis

The proanthocyanidins are one of the most ubiquitous groups of all plant phenols, being commonly found in numerous woody and some herbaceous higher plant species. ${ }^{1,2}$ Noticeable in vitro biological and pharmacological activities have been found for this class of compounds, including antioxidant, antitumor, antimicrobial, enzyme-inhibiting, and radical-scavenging properties. ${ }^{3-5)}$ The presence of tannins in fairly high concentrations has commonly been used to explain, among others, the claimed efficacy of a variety of traditional plants for treatment of infectious conditions. Although polyphenols are generally regarded as having potent antimicrobial activity, recent evidence on chemically defined compounds suggested otherwise. $\left.{ }^{6}\right)$ Having in mind the limited knowledge on the uptake of tannins in humans, this calls into question their hitherto assumed direct action on pathogens at various internal targets in vivo. In principle, the claimed medicinal efficacy in infectious conditions could be explained by antibacterial activities and/or stimulation of the nonspecific immune system.

As an integral part of the innate immune system, macrophages $(M \Phi)$ form a first line of defense against invading microorganisms. Furthermore, as antigen-presenting and regulatory cells, $M \Phi$ provide an essential link to the specific, lymphocyte-mediated immune response in the course of which they may be further activated, e.g. by interferon (IFN- $\gamma)$ for enhanced microbicidal activity. On the other hand, $M \Phi$ are host cells for a variety of bacterial and protozoal pathogens such as Leishmania. Species of the parasitic protozoa Leishmania are estimated to threaten some 350 million people with a broad range of diseases and to infect an estimated 1.4 million people annually world-wide. ${ }^{7)}$ An in vitro infection model with obligate intracellular Leishmania parasites is a valuable tool for assessing both antiparasitic and immunomodulatory potency of lead structures for potential therapeutics.

In a recent study, we have evaluated a series of hydrolyzable tannins for their antileishmanial activity and immunomodulatory effects on macrophage functions. ${ }^{8)}$ All hydrolyzable tannins examined were found to be significantly leishmanicidal against intracellular Leishmania donovani amastigotes but inactive against extracellular promastigotes, suggesting activation of macrophage functions. Since leishmaniasis is a major public health problem, ${ }^{7}$ this observation was highly significant in that standard therapeutics have severe side-effects and that the development of resistant parasite strains has created an urgent need for new antileishmanial drugs. ${ }^{9)}$ Independent supporting evidence for macrophage activation was available from detection of nitric oxide (NO) and tumor necrosis factor (TNF) in supernatants of sample-treated macrophage cultures. Also, some representa- 
tives of the compounds have revealed significant interferon (IFN)-like activity in an anti-virus/fibroblast protection assay. In the continuation of our research program to identify novel antileishmanial compounds and to unravel the antiinfectious mode of action of polyphenols present in herbal medicines, we now disclose detailed results of relevance to the antileishmanial potency and immunomodulatory activity of proanthocyanidins and related compounds for release of NO, TNF and IFN-like activity.

\section{MATERIALS AND METHODS}

Compounds The polyphenols used were those isolated and characterized by the research groups of the authors. ${ }^{10-17)}$ Sodium stibogluconate (Pentostam ${ }^{\circledR}$; kindly provided by Dr. Goldbach, Glaxo Wellcome, Germany) and amphotericin B (Sigma, Deisenhofen, Germany) were used as standard drugs for comparison of the antileishmanial activity. Recombinant murine-gamma-interferon ( $\mathrm{rIFN}-\gamma)$, expressed in $E$. coli, was produced by Genentech, San Francisco, U.S.A. and kindly provided by Bender \& Co., Wien, Austria.

Culture Media RPMI 1640 medium (supplemented with 5 or $10 \%$ heat-inactivated fetal calf serum; herein designated R5 or R10), HBSS (Hanks' balanced salt solution), and PBS (phosphate-buffered saline) were purchased from GIBCO Life Technologies Ltd. (Paisley, U.K.), Leishmania growth medium (GM) consisted of RPMI 1640 supplemented with $5 \%$ fetal calf serum, 15\% macrophage-conditioned medium, $100 \mathrm{U} / \mathrm{ml}$ penicillin, $100 \mu \mathrm{g} / \mathrm{ml}$ streptomycin, $20 \mathrm{~mm}$ Na-pyruvate, and hemin (solution B of Hosmem II medium), lysis medium of HEPES-buffered RPMI containing $0.008 \%$ sodium dodecyl sulfate (SDS), and postlysismedium of GM with all supplements in 1.6-fold concentration.

Parasites Leishmania donovani LV9 organisms were maintained by animal passage and cryopreserved in liquid nitrogen. Promastigotes were cultured in $\mathrm{GM}$ at $25^{\circ} \mathrm{C}, 5 \% \mathrm{CO}_{2}$ in a humidified incubator. The cultures were passaged every $3-4 \mathrm{~d}$.

Macrophage-like RAW 264.7 Cells The murine macrophage-like cell line, RAW 264.7, was kindly supplied by Dr. M. Masihi, Robert Koch-Institut, Berlin, Germany. These plastic adherent cells were kept in R10 medium in tissue culture flasks (Falcon, Becton Dickinson). Subcultures were performed when cell layers had reached confluency. For detachment, medium was replaced by cold $\mathrm{Ca}^{2+} / \mathrm{Mg}^{2+}$-free phosphate-buffered saline and the cells chilled at $4{ }^{\circ} \mathrm{C}$ for at least $30 \mathrm{~min}$. Cells remaining loosely adherent were detached by rigorously tapping the bottom of the flask.

Assay for Extracellular Leishmanicidal Activity The direct effect of polyphenols on the viability of Leishmania promastigotes was assessed by monitoring the MTT [3-(4,5dimethylthiazol-2-yl)-2,5-diphenyl-tetrazolium bromide] metabolism after a 96-h culture period in the presence of the respective phenolic sample. ${ }^{18)}$ Parasites in the stationary culture stage were seeded at $1 \times 10^{4} / 100 \mu \mathrm{l} \mathrm{R} 5 /$ well in 96-well flat-bottom microtiter plates. Further $100 \mu \mathrm{l} \mathrm{R5/well} \mathrm{with}$ different concentrations of test compounds or drug standards dissolved in DMSO were added to achieve final concentration of $50 \mu \mathrm{g} / \mathrm{ml}$ and serial two-fold dilutions thereof for each compound. All experiments were performed in dupli- cate. Parallel dilutions of DMSO alone did not affect the growth of promastigotes. Following an incubation period of $92 \mathrm{~h}$ at $25^{\circ} \mathrm{C}$, MTT $(20 \mu \mathrm{l} /$ well of a $5 \mathrm{mg} / \mathrm{ml}$ PBS stock solution) was added. After 4-6h MTT processing was stopped and formazan crystals solubilized by adding $50 \mu \mathrm{l} /$ well acidified SDS (20\%) and incubating over night at $37^{\circ} \mathrm{C}$. The relative amount of formazan/well produced by viable cells was determined spectrophotometrically at $570 \mathrm{~nm}$ by blanking against an appropriate control. Leishmanicidal effects were expressed as $\mathrm{EC}_{50}$ values, indicating the concentration of a compound which provoked a $50 \%$ reduction in viability of the parasite.

In Vitro Infection of RAW Cells with Leishmania donovani $6 \times 10^{4}$ RAW cells/ml R10 medium were incubated with $4 \times 10^{7}$ L. donovani promastigotes $/ 500 \mu \mathrm{l}$ medium in stationary growth phase (ratio macrophage/L. donovani $1: 8$ ) for $2 \mathrm{~h}$ at $37^{\circ} \mathrm{C}$ in $\mathrm{CO}_{2}$ atmosphere ${ }^{18,19)}$ in $10 \mathrm{ml}$ polypropylene tubes (Falcon). The cells were then washed with $10 \mathrm{ml}$ HBSS, centrifuged for $8 \mathrm{~min}$ at $200 \times \boldsymbol{g}$ at $6^{\circ} \mathrm{C}$, and the supernatant discarded. The residual pellet was re-suspended in $6.5 \mathrm{ml} \mathrm{HBSS}$ and the process repeated four times. Aliquots of the final suspension $\left(1 \times 10^{6}\right.$ infected cells $\left./ \mathrm{ml}\right)$ were seeded at $1 \times 10^{5} \mathrm{RAW}$ cells/ $100 \mu \mathrm{l} \mathrm{R} 10 /$ well in 96-well microtiter plates and incubated for $24 \mathrm{~h}$ at $37^{\circ} \mathrm{C}$ to allow internalized Leishmania to transform into the amastigote form.

Assay for Intracellular Leishmanicidal Activity In vitro infected RAW cells $\left(1 \times 10^{5} / 100 \mu \mathrm{l} /\right.$ well $)$ were mixed with $100 \mu \mathrm{l}$ R10/well containing different concentrations (final sample concentration $50 \mu \mathrm{g} / \mathrm{ml}$, and serial two-fold dilutions thereof) of test compounds or drug standards dissolved in DMSO in a final volume of $200 \mu \mathrm{l}$ R10 medium. In these conditions, none of the DMSO dilutions affected intracellular parasite survival. Each concentration was tested in duplicate. After incubation at $37^{\circ} \mathrm{C}$ for $72 \mathrm{~h}$, RAW cells were treated with $37^{\circ} \mathrm{C}$ lysis medium and then incubated with $100 \mu \mathrm{l} /$ well freshly prepared lysis buffer for $7-20 \mathrm{~min}$ during which macrophage disintegration was regularly monitored with an inverted microscope. Once more than $c a .95 \%$ of host cells appeared lysed, $150 \mu \mathrm{l} /$ well post-lysis medium was added to stop SDS-lysis and to create optimal growth conditions for Leishmania parasites. The lysates were then incubated at $25^{\circ} \mathrm{C}$ for $3-4 \mathrm{~d}$ to allow viable parasites to transform back to promastigotes. The relative number of viable Leishmania/well was determined using the MTT assay as described above for the extracellular assay. Leishmanicidal effects were expressed as $\mathrm{EC}_{50}$ values, indicating the concentration of a compound which provoked a $50 \%$ reduction in intracellular survival of the parasite.

Assay for Cytotoxic Activity against Host Cells Noninfected RAW cells were exposed to linear two-fold dilutions of test compounds for $72 \mathrm{~h}$ directly in parallel to the assay for intracellular leishmanicidal activity described above. MTT was added for the final $6 \mathrm{~h}$ and cytotoxic effects expressed as the concentration of a compound which provoked a $50 \%$ reduction in cell viability compared to RAW cultures in R10 medium alone.

Assay for NO Production by Activated RAW $\Phi$ The murine macrophage cell line (RAW 264.7) was cultured in R10 medium at $37^{\circ} \mathrm{C}, 5 \% \mathrm{CO}_{2}$ in humidified air. Cells were seeded at $1 \times 10^{5} / \mathrm{ml}$ in 96 -well microtiter plates and were activated by incubating in the same medium containing 
$50 \mu \mathrm{g} / \mathrm{ml}$ of test compounds. After $48 \mathrm{~h}$, the supernatants were collected as a source of secreted NO which were quantitated by determining the nitrite concentration using the Griess assay. ${ }^{18,20)}$ Aliquots of $100 \mu \mathrm{l}$ of the supernatant were mixed with $100 \mu \mathrm{l}$ of Griess reagents $(1 \%$ sulfanilamide $/ 0.1 \%$ naphthylethylendiamine dihydrochloride $/ 3 \%$ $\mathrm{H}_{3} \mathrm{PO}_{4}$ ). After the chromophore was formed at room temperature for $5 \mathrm{~min}$, absorbance was determined at $550 \mathrm{~nm}$. The nitrite concentration was calculated from a standard curve generated with $\mathrm{NaNO}_{2}$. The experiments were performed in duplicates.

Inhibition of iNO Synthase The activity of inducible NO synthase (iNOS) in treated RAW cells was determined after cell lysis. In short, RAW cells were incubated in 96-well microtiter plates (Falcon) with test compounds or with $100 \mathrm{U}$ IFN- $\gamma$ plus $20 \mathrm{ng}$ LPS for positive control in a final volume of $200 \mu \mathrm{l} /$ well. In parallel cultures, iNOS activity was blocked from the beginning by adding $2 \%(\mathrm{~m} / \mathrm{v}) N^{(\mathrm{G})}$ monomethyl-L-arginine (L-NMMA). After $72 \mathrm{~h}$, cell lysis was performed by discarding the culture medium and transferring the cells into tubes containing $10 \mathrm{ml} \mathrm{R} 10$ with $1 \mathrm{ml}$ proteinase Tris buffer solution and mechanical disruption (scraping and vigorous pipetting). To enhance enzyme stability, $100 \mu \mathrm{l}$ ATP $(0.1 \mathrm{~mm}), 50 \mu \mathrm{l}$ coenzyme-A $(0.05 \mathrm{~mm})$ and $50 \mu \mathrm{l}$ of a $2 \%$ solution of $\mathrm{L}$-arginine were added. The lysates were incubated for another $24 \mathrm{~h}$ at $37^{\circ} \mathrm{C}$. Activity of iNOS was determined using a HPLC method for determining amino acids. ${ }^{21)}$ The assay is based on the ability of iNOS to oxidise L-arginine to give citrulline and NO-radical. Detection of amino acids was achieved by their derivatization with ortho-diphthalaldehyde using a fluorescence detector. Since citrulline is easily converted into ornithine, both L-arginine and citrulline (ornithine) were quantified using homoserine as internal standard.

Assay for TNF Release RAW cultures were incubated in R10 medium in 96-well flat-bottom microtiter plates. Cells were allowed to adhere overnight, then non-adherent cells were gently washed out twice with fresh medium. Remaining adherent cells were seeded at $5 \times 10^{4} / 100 \mu \mathrm{l}$ R10/well with $(50 \mu \mathrm{g} / \mathrm{ml})$ or without test samples in a final volume of $200 \mu \mathrm{l}$ R10 medium. The first well was serially diluted through 12 wells in each instance. Treatment with bacterial endotoxin (Salmonella abortusequi) at $100 \mathrm{ng} \mathrm{LPS} / \mathrm{ml}$ served as positive control for TNF induction. After $18 \mathrm{~h}$ of incubation in a humidified incubator at $37^{\circ} \mathrm{C}$ and $6 \% \mathrm{CO}_{2}$, the supernatants of the RAW cells were collected and stored at $-20^{\circ} \mathrm{C}$. For determining TNF activity, TNF-sensitive murine L929 fibroblasts were seeded at $3 \times 10^{4} / 100 \mu \mathrm{l}$ R/well in microtiter plates and incubated overnight to achieve a monolayer of cells in late logarithmic growth phase. Culture supernatants were then replaced by fresh medium containing actinomycin $\mathrm{D}$ to inhibit further proliferation of the cell line and render L929 cells more sensitive for the cytotoxic effect of TNF. Serial $1: 2$ dilutions of samples were carefully performed over the monolayer together with recombinant murine TNF- $\alpha$ as positive control. Media additives were calculated for final concentrations of $2 \mu \mathrm{g} / \mathrm{ml}$ actinomycin D and 5\% FCS in all wells. Following an incubation period of $18 \mathrm{~h}$, culture supernatants were replaced by methanolic crystal violet, thereby staining all intact cells. Dead cells and excess of the dye reagent were removed by washing the plates with distilled
$\mathrm{H}_{2} \mathrm{O}$. After drying, the remaining dye crystals were dissolved in acetic acid and the preparations subjected to spectral photometric analysis. Relative optical density, correlating with the relative amount of viable cells/well was measured at $570 \mathrm{~nm}$. TNF units $/ \mathrm{ml}$ were calculated as the reciprocal values of the TNF-containing supernatant dilution that would cause $50 \%$ lysis of L929 cells. These values were correlated with the recombinant TNF standard to account for fluctuation in assay sensitivity. This functional assay does not discriminate between TNF- $\alpha$ and $-\beta$.

Assay for IFN Induction and Detection of IFN-Activity $1 \times 10^{5} \mathrm{RAW}$ cells $/ 200 \mu \mathrm{l}$ R5/well were incubated for $48 \mathrm{~h}$ with test compounds $(50 \mu \mathrm{g} / \mathrm{ml})$ or medium alone before further FCS ( $10 \%$ final concentration) was added and the supernatants removed and stored at $-20{ }^{\circ} \mathrm{C}$. Interferon activity was assessed as capacity to protect murine L929 fibroblasts from the cytopathic effect of murine encephalomyocarditis virus (EMCV, generously provided by Lohmann-Matthes, Fraunhofer Institute of Toxicology, Hannover, Germany) in a modification of the method reported previously. ${ }^{22)}$ In brief, a monolayer of EMCV- and IFN-sensitive murine L929 fibroblasts $\left(2 \times 10^{4}\right.$ cell/ $100 \mu \mathrm{l}$ R5/well) was incubated in R5 alone or with dilutions of the experimental culture supernatants described above. After $8 \mathrm{~h}, 100 \mu \mathrm{l}$ of a pretested EMCV suspension was added to each well and the cells incubated for another $18-24 \mathrm{~h}$. Within this period, nonprotected cells disintegrated due to the cytopathic effect of the virus. The relative number of viable cells per well was assessed colorimetrically by the crystal violet method as described above for the TNF bioassay. The cytoprotective effect of tannin-stimulated RAW cell supernatants was compared to that of recombinant murine IFN- $\gamma$. Antiviral protection (IFN activity) was expressed in units $/ \mathrm{ml}$, defined as reciprocal value of the supernatant dilution that would inhibit $50 \%$ of the cytopathic effect induced by EMCV on L929 cells. These values were correlated with the IFN standard to account for any fluctuation in assay sensitivity. This functional assay does not discriminate between IFN- $\alpha,-\beta$, and $-\gamma$.

\section{RESULTS AND DISCUSSION}

Starting with the antileishmanial activity of the polyphenolic samples, the activity of compounds $\mathbf{1}-\mathbf{1 7}$ was assessed against both extracellular promastigotes and intracellular amastigotes of Leishmania donovani (Table 1). As a parameter for antileishmanial activity, the $\mathrm{EC}_{50}$ value, the sample concentration causing $50 \%$ reduction in survival/viability of the parasites, was used. With $\mathrm{EC}_{50}$ values ranging from 0.8 $10.6 \mathrm{~nm}$, all test compounds were considerably leishmanicidal against $L$. donovani amastigotes but catechin (1), cinchonain Ia (6) and $5^{\prime}, 5^{\prime}$-bisdihydroquercetin (17) were relatively weaker $(>41 \mathrm{~nm})$ in our in vitro experiments, when compared with the $\mathrm{EC}_{50}$ value $10.6 \mathrm{~nm}$ of the therapeutically used antileishmanial drug, sodium stibogluconat (Pentostam ${ }^{\circledR}$ ), as a reference compound. Compounds 10, 14 and 16 exhibited the highest relative toxicity for intracellularly persisting $L$. donovani parasites with an $\mathrm{EC}_{50}$ of $0.7-0.9 \mathrm{~nm}$. In contrast, none of these compounds showed selective toxicity when tested against $L$. donovani promastigotes $\left(\mathrm{EC}_{50} 7.8\right.$ to $>86 \mathrm{~nm}$ ). This finding suggest an amastigote-specific activity of the polyphenols, provided that these compounds reach the 


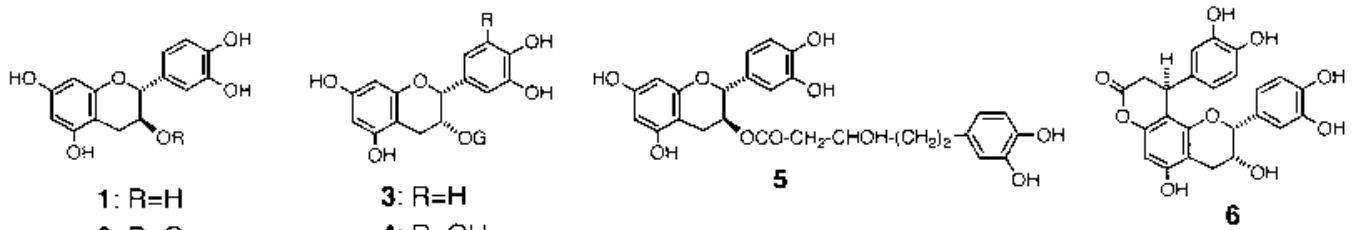

$$
\text { 2. } \mathrm{R}=\mathrm{G} \quad \text { 4: } \mathrm{R}=\mathrm{OH}
$$

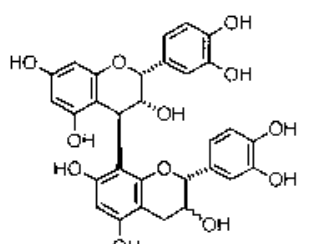<smiles>Oc1cc(O)c2c(c1)OC(c1ccc(O)c(O)c1)[C@H](O)[C@H]2c1c(O)cc(O)c2c1O[C@H](c1ccc(O)c(O)c1)C[C@H]2O</smiles>

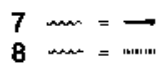

$\begin{aligned} 9 & =\longrightarrow \\ \text { to } & =\longrightarrow\end{aligned}$

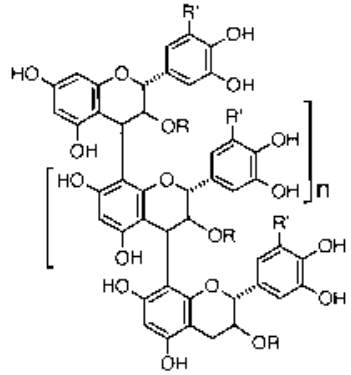

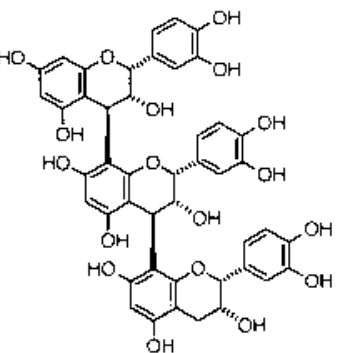

11<smiles>C[C@H]1[C@@H](c2ccc(O)c(O)c2)Oc2c(c(O)cc(O)c2[C@H]2c3c(O)cc(O)cc3O[C@H](c3ccc(O)c(O)c3)[C@@H]2O)[C@@H]1c1c(O)cc(O)c2c1O[C@H](c1ccc(O)c(O)c1)C[C@@H]2O</smiles>

$$
\begin{aligned}
& \text { 13: } R=F^{\prime}=H \\
& \text { 14: } R=G, R^{\prime}=H \\
& \text { 15: } R=H, R^{\prime}=O H
\end{aligned}
$$

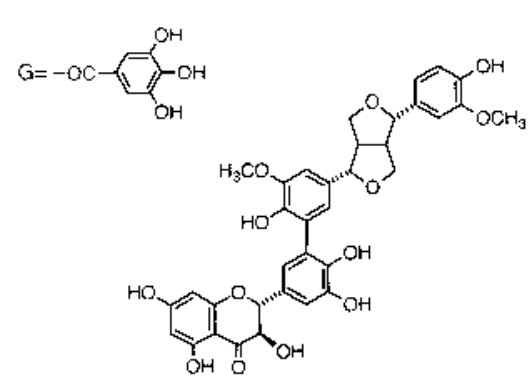

16

\begin{tabular}{|c|c|c|c|}
\hline \multirow{2}{*}{ Compound } & \multicolumn{2}{|c|}{ Leishmanicidal activity } & \multirow{2}{*}{ Toxicity for RAW cells } \\
\hline & Extracellular & Intracellular & \\
\hline \multicolumn{4}{|l|}{ Flavan-3-ols and related compounds } \\
\hline 1 Catechin & $>86.2$ & 50.3 & 67.9 \\
\hline 2 Catechin 3-gallate & $>56.6$ & 10.6 & $>56.6$ \\
\hline 3 Epicatechin 3-gallate & $>56.6$ & 10.6 & $>56.6$ \\
\hline 4 Epigallocatechin 3-gallate & $>54.6$ & 9.6 & $>54.6$ \\
\hline 5 Phylloflavan & $>50.2$ & 3.2 & $>50.2$ \\
\hline 6 Cinchonain Ia & $>55.3$ & $>55.3$ & $>55.3$ \\
\hline \multicolumn{4}{|l|}{ Proanthocyanidins } \\
\hline 7 Procyanidin B-1 & $>43.0$ & 6.5 & $>43.0$ \\
\hline 8 Procyanidin B-2 & $>43.0$ & 2.9 & $>43.0$ \\
\hline 9 Procyanidin B-3 & $>43.0$ & 1.4 & $>43.0$ \\
\hline 10 Procyanidin B-4 & $>43.0$ & 0.8 & $>43.0$ \\
\hline 11 Procyanidin C-1 & $>28.8$ & 6.7 & $>28.8$ \\
\hline 12 Procyanidin C-2 & $>28.8$ & 7.7 & $>28.8$ \\
\hline 13 Procyanidin polymer ${ }^{c)}$ & $>7.8$ & 3.4 & $>7.8$ \\
\hline 14 Procyanidin 3-gallate polymer ${ }^{d)}$ & $>10.6$ & 0.7 & $>10.6$ \\
\hline 15 Prodelphinidin polymeric ${ }^{e)}$ & $>13.6$ & 4.2 & $>13.6$ \\
\hline \multicolumn{4}{|l|}{ Miscellaneous } \\
\hline 16 Pseudotsuganol & $>37.8$ & 0.9 & $>37.8$ \\
\hline 17 5,5'-Bisdihydroquercetin & $>41.2$ & $>41.2$ & $>41.2$ \\
\hline \multicolumn{4}{|l|}{ References } \\
\hline Pentostam & 3.5 & 10.6 & n.d. ${ }^{b)}$ \\
\hline Amphotericin B & 0.03 & 0.3 & n.d. ${ }^{b)}$ \\
\hline
\end{tabular}<smiles>O=C1Oc2c(cc(C3c4cc(O)cc(O)c4C(=O)C(O)C3O)cc2-c2cc(O)c(O)c(O)c2)Oc2cc(O)cc(O)c21</smiles>

17

Table 1. Antileishmanial Activity (L. donovani) and Toxicity for RAW Host Cells of Compounds $\mathbf{1}-\mathbf{1 7}$ [EC Salues $_{\text {(nM) }}$ ]

a) The activity against promastigotes is probably due to the presence of the preservative, chlorocresol. $\left.{ }^{6} \quad b\right)$ n.d., not determined. $\quad c$ ) Undecamer with epicatechin constituent units. $^{17)} d$ ) Hexamer with a procyanidin/prodelphinidin ratio of $90: 10$, a ratio of cis/trans units of $45: 55$, and a degree of 3-O-galloylation of about $60 \%$. ${ }^{15}$ ) $e$ ) Hexamer with a ratio of cis/trans units of $65: 35 .^{14}$

parasitic vacuole within the host cell. On the other hand, antiparasitic compounds might function indirectly by activating $\mathrm{M} \Phi$ for leishmanicidal functions as has been demonstrated for the physiological $M \Phi$ activator IFN- $\gamma$. It is noteworthy that all compounds exhibited no cytotoxicity against the murine host cells $\left(\mathrm{EC}_{50} 7.8\right.$ to $\left.>56 \mathrm{~nm}\right)$.

Some interesting structural features also emerged from the study in connection with structure-activity relationships. Ap- 
parently the marked leishmanicidal potency of flavan-3-ols is associated with the presence of 3-O-acyl groups as evident from the activity of compounds $\mathbf{1}-\mathbf{6}$. For proanthocyanidins, comparison of antileishmanial activity indicated that $4 \alpha, 8$ coupled dimers $(9,10)$ were more active than their $4 \beta, 8$ counterparts $(\mathbf{7}, \mathbf{8})$ (Table 1$)$. It also appeared that an increase in molecular weights, galloylation of constituent units or the presence of predominantly 2,3-cis flavanyl chain extender units also enhancd antileishmanial activity, as evident from the comparison of the antiprotozoal effects of the polymers (13-15). Conspicuously, pseudotsuganol (16) was found to show marked antileishmanial activity $\left(\mathrm{EC}_{50} 0.9 \mathrm{~nm}\right)$. Since compound $\mathbf{1 7}$ was inactive, this finding implicated that the crucial structural element for activity of $\mathbf{1 6}$ may be due to the pinoresinol moiety rather than the taxifolin unit, consistent with reports on the antiprotozoal activity of lignans. ${ }^{23,24)}$

Next, we assessed the immunostimulating potential of compounds 1-17. First experiments have focused on the evaluation of $\mathbf{1}-\mathbf{1 7}$ on the release of nitric oxide (NO), using the Griess assay. ${ }^{18,20)}$ Reactive nitrogen intermediates, NO radicals and the metabolic products thereof, play a firmly established role as antimicrobial effector molecules produced by activated $M \Phi^{22,25,26)}$ Compared with the stimulus rIFN$\gamma /$ lipopolysaccharide (LPS) $(119 \mu \mathrm{M}$ NO), the NO-inducing effect of all the samples was found to be only moderate, ranging from $8-26 \mu \mathrm{M}$ (Table 2). In the Leishmania infection model, the intracellular parasite kill did not correlate with enhanced NO-levels, when compared to the kill/NO relationship in LPS/IFN-activated RAW cells. One possible explanation is that polyphenols acted as scavengers for extracellular NO radicals, thus rendering extracellular NO non-detectable for the Griess assay, while the intracellular leishmanicidal activity of NO-radicals remained unaffected. In order to further assess the role of the inducible NO synthase (iNOS) in cytotoxic mechanisms against Leishmania parasites in stimulated RAW cells, a modified experimental approach was designed. In an additional set of experiments, the leishmanicidal effect of gallic acid was tested in parallel incubations with and without $N^{(\mathrm{G})}$-monomethyl-L-arginine (LNMMA), a well-known inhibitor of iNOS, and the number of surviving organisms of $L$. donovani was determined. Selection of gallic acid was simply for convenience, but it also represents a potent NO-inducer $(54 \mu \mathrm{M})$. This comparative study indicated significant differences in the leishmanicidal effects in the assay with and without inhibitor (survival rate of parasites $<1 \%$ and $c a$. $60 \%$, respectively). Although the involvement of additional leishmanicidal mechanisms in RAW cells activated with polyphenols can not be excluded, this finding provided strong evidence for the crucial role of NO as toxic effector molecule in the host defense to microbial infections.

Tumor necrosis factor (TNF) plays an important role in the network of cytokines including the activation of immune cells and is required for host defense against certain pathogens. ${ }^{27,28)}$ Since there is an intimate and causal relationship between the stimulation of this pleiotropic cytokine produced by activated macrophages and the triggered NO production, ${ }^{29)}$ it appeared meaningful to examine the inducing potential of $\mathbf{1}-\mathbf{1 7}$ for the release of the cytokine, TNF- $\alpha$. This factor was assayed by a protocol of spectrophotometrically determining the relative amount of viable L929 cells,
Table 2. NO-, TNF- and IFN-inducing Potential of Compounds $\mathbf{1}-\mathbf{1 7}$ in RAW Cells

\begin{tabular}{lrrr}
\hline \multicolumn{1}{c}{ Compound $^{a)}$} & $\mathrm{NO}^{b)}$ & $\mathrm{TNF}^{c)}$ & $\mathrm{IFN}^{d)}$ \\
\hline Flavan-3-ols and related compounds & & & \\
1 Catechin & 17 & 48 & \\
2 Catechin 3-gallate & 19 & 98 & \\
3 Epicatechin 3-gallate & 24 & 138 & 11 \\
4 Epigallocatechin 3-gallate & 14 & 127 & 12 \\
5 Phylloflavan & 8 & n.d. ${ }^{e}$ & 38 \\
6 Cinchonain Ia & 18 & n.d. ${ }^{e}$ & $<5$ \\
Proanthocyanidins & & & \\
7 Procyanidin B-1 & 21 & 64 & $<5$ \\
8 Procyanidin B-2 & 19 & 56 & 7 \\
9 Procyanidin B-3 & 18 & 32 & $<5$ \\
10 Procyanidin B-4 & 21 & 60 & $<5$ \\
11 Procyanidin C-1 & 17 & 62 & 9 \\
12 Procyanidin C-2 & 24 & 68 & 8 \\
13 Polymeric procyanidin & 16 & 31 & 12 \\
14 Polymer procyanidin 3-gallate & 14 & n.d. ${ }^{e}$ & 6 \\
15 Polymeric prodelphinidin & 16 & n.d. ${ }^{e}$ & 36 \\
16 Pseudotsuganol & 20 & n.d. ${ }^{e}$ & 6 \\
17 5,5'-Bisdihydroquercetin & 21 & n.d. ${ }^{e}$ & 6 \\
Reference & & & \\
IFN (100 U/ml)/LPS (10 ng/ml) & 119 & 184.0 & - \\
\hline
\end{tabular}

a) Sample concentration $50 \mu \mathrm{g} / \mathrm{ml}$. b) $\mu \mathrm{M}$. c) $\mathrm{U} / \mathrm{ml}$, calculated as the reciprocal of the values of the macrophage supernatant dilution that would cause $50 \%$ lysis of the L929 cells. d) U/ml, calculated as the reciprocal of the values of the macrophage supernatant dilution that would cause $50 \%$ inhibition of the cytopathic effects of EMC virus on L929 cells. e) n.d., not detectable.

treated with supernatant cultures of sample-activated RAW cells; the cytopathic effect of TNF present in these supernatants being reflected by cell lysis. At the host cell subtoxic concentration of $50 \mu \mathrm{g} / \mathrm{ml}$, the TNF-inducing potential of the polyphenols producing 50\% lysis in murine L929 fibroblast cells ranged from inactive $(\mathbf{5}, \mathbf{6}, \mathbf{1 4}-\mathbf{1 7})$ to fairly high actions (138 and $127 \mathrm{U} / \mathrm{ml}$ for $\mathbf{3}$ and $\mathbf{4}$, respectively) (Table 2). In the series of flavanol derivatives, representatives possessing galloyl groups $(\mathbf{2}-\mathbf{4})$, were found to possess the greatest TNF-inducing potential. Within the group of proanthocyanidins, the dimers $(\mathbf{7}-\mathbf{1 0})$ and the trimers $(\mathbf{1 1}, \mathbf{1 2})$ showed similar moderate capabilities $(32-68 \mathrm{U} / \mathrm{ml})$, while an increased degree of polymerization is apparently less favorably, as evidenced by the absence of effects of the polymers (14, 15) on TNF-induced cytotoxicity in murine L929 fibroblast cells. The moderate inducing potential of polymer (13) may be attributable to the generally polydisperse character of highly polymerized proanthocyanidins, involving the presence of minor components of lower degree of condensation.

Numerous lines of evidence indicate that IFN- $\gamma$ endowed with potent immunomodulatory effects on a variety of immune cells is a further powerful factor in the battery of nonspecific immune defense mechanisms. ${ }^{30-40)}$ Macrophage functions are intimately related to the IFN system. ${ }^{32)}$ Only recently, it became evident that macrophages produce not only IFN- $\alpha$ but also, at least under certain conditions, IFN- $\gamma \cdot{ }^{33)}$ Our recent finding that stimulated RAW cells express IFN- $\gamma$ mRNA, as evidenced by RT-PCR analysis, ${ }^{41)}$ is consistent with these reports. Accordingly, attention was given to possible IFN-like activities of polyphenols induced in RAW cells. For this, supernatants of sample-activated RAW cells were analysed for their capacity to protect L929 cells from the cytopathic effect of encephalomyocarditis virus (EMCV). Appropriate controls were performed using medium alone 
as negative and an recombinant murine IFN- $\gamma$ standard $(100 \mathrm{U} / \mathrm{ml})$ as positive control for cytoprotection. Of the series of polyphenols tested, only phylloflavan (5) and the polymer (15) (38 and $36 \mathrm{U} / \mathrm{ml})$ inhibited the cytopathic effect of murine EMC virus on IFN- and virus-sensitive L929 fibroblasts, whereas the remaining samples exhibited only negligible or weak cytoprotective effects (Table 2).

In conclusion, our study provides first evidence that flavan-based analogues contribute to the crucial transformation of macrophage-like RAW cells from host cells to leishmanicidal effector cells, albeit with moderate potential. Importantly, all test compounds were first subjected to assays for endotoxin contamination (Limulus amoebocyte lysate method), which may stimulate immune cells, of which we found no evidence. Furthermore, the demonstrated immunological responses provide valuable clues for the claimed efficacy of traditional polyphenol-containing herbal medicines in infectious conditions. In this context, some previous reports on the activation of phagocytes, immune cells, and production of interleukin-1 by polyphenols deserve explicit mention. ${ }^{34-40)}$ No doubt, from the results so far obtained there is ample justification for more extensive investigations in this highly complex area aimed at a better understanding towards the immunomodulating activities of polyphenols.

Acknowledgment The authors thank Ulrike Folkens for her skilled technical assistance.

\section{REFERENCES}

1) Porter L. J., "The Flavonoids. Advances in Research since 1986," ed. by Harborne J. B., London, Chapman and Hall, 1994, pp. 21-64.

2) Porter L. J., Hemingway R. W., "Natural Products of Woody Plants I," ed. by Rowe J. W., Springer, Berlin, 1989, pp. 571-651.

3) Haslam E., Lilley T. H., Cai Y., Martin R., Magnolato D., Planta Med., 55, 1-8 (1989).

4) Okuda T., Yoshida T., Hatano T., "Phenolic Compounds in Food and Their Effects on Health, II," ed. by Huang M.-T., Ho C.-T., Lee C. Y., ACS Symposium Series 507, Washington, 1992, pp. 87-97.

5) Haslam E., J. Nat. Prod., 59, 205-215 (1996).

6) Kolodziej H., Kayser O., Latté K. P., Ferreira D., Planta Med., 65, 444-446 (1999).

7) Ashford R. W., Desjeux P., DeRaadt P., Parasitol. Today, 8, 104-105 (1992).

8) Kolodziej H., Kayser O., Kiderlen A. F., Ito H., Hatano T., Yoshida T., Foo L. Y., Planta Med. (in press).

9) Bermann J. D., Clin. Infect. Dis., 24, 684-703 (1997).

10) Kolodziej H., Phytochemistry, 25, 1209-1215 (1986).

11) Foo L. Y., Karchesy J., J. Chem. Soc., Chem. Commun., 1989, $217-$ 219

12) Foo L. Y., Phytochemistry, 26, 2825-2830 (1987).
13) Foo L. Y., Helm R., Karchesy J., Phytochemistry, 31, 1444-1445 (1992).

14) Foo L. Y., Lu Y., Molan A. L., Woodfield D. R., McNabb W. C., Phytochemistry, 54, 539-548 (2000).

15) Lu F., Foo L. Y., "Nutrition, Lipids, Health and Disease," ed. by Ong A. S. H., Niki E., Packer L., AOCS Press, Champaign, Illinois, 1995 , pp. $86-95$.

16) Okuda T., Yoshida T., Hatano T., Mori K., Fukuda T., J. Liq. Chromatogr., 13, 3637-3650.

17) Ito H., Kobayashi E., Li S., Hatano T., Sakagami H., Kusama K., Sato K., Sugita D., Shimura S., Itoh Y., Yoshida T., Chem. Pharm. Bull., 48, 687-693 (2000).

18) Kiderlen A. F., Kaye P. M., J. Immunol. Methods, 127, 11-17 (1990).

19) Mauel J., Behin R., Biroum-Noerjasin D. S., Nature New Biol., 244, 93-108 (1973).

20) Ding A. H., Nathan C. F., Stuehr D. J., J. Immunol., 141, 2407-2412 (1988).

21) Algermissen B., Nundel M., Riedel E., GIT Fachz LAB, 33, 783-790 (1989).

22) Marcucci F., Klein B., Kirchner M., Zawatzky R., Eur. J. Immunol., 12, 787-790 (1982)

23) Barata L. E. S., Santos L. S., Ferri P. H., Phillipson J. D., Paine A., Croft S. L., Phytochemistry, 55, 589-595 (2000).

24) Bastos J. K., Albuquerque S., Silva M. L. A., Planta Med., 65, 541544 (1999).

25) Moncarda S., Palmer R. M. J., Higgs E. A., Pharmacol. Rev., 43, 109-142 (1991).

26) Nussler A. K., Biliar T. R., J. Leuk. Biol., 54, 171-178 (1993).

27) Nathan C. F., Hibbs J. B., Curr. Opin. Immunol., 3, 65-70 (1991).

28) Zidek Z., Tuckova L,. Mara M., Barot-Ciorbaru R., Prokesova L., Tlaskalova-Hogenova H., Int. J. Immunopharmacol., 20, 359 (1998).

29) Rege A. A., Huang K., Aggaewal B. B., "Cytokine Therapy,” ed. by Galvani D. W., Cawley J. C., Cambridge University Press, Cambridge, 1992, pp. $152-168$.

30) Thiemermann C., Wu C., Szabo C., Perretti M., Vane J., Br. J. Pharmacol., 182, 591-595 (1993).

31) Young H. A., Hardy K. J., J. Leuk. Biol., 58, 373-381 (1995).

32) Billiau A., Advances Immunol., 62, 61-130 (1995).

33) Mogensen S. C., Virelizier J.-L., Interferon, 8, 55-84 (1987)

34) Gessani S., Belardelli F., Cytokine Growth Factor Rev., 9, 117-123 (1998).

35) Sakagami H., Asano K., Hara Y., Shimamura T., J. Leukocyte Biol., 51, 478-483 (1992).

36) Sakagami H., Asano K., Tanuma S.-I., Hatano T., Yoshida T., Okuda T., Anticancer Res., 12, 377-388 (1992).

37) Daniel P. T., Falconi F., Berg A. U. J., Berg P. A., Meth. Find. Exptl. Clin. Pharmacol., 8, 139-145 (1986).

38) Rauch G., Meth. Find. Exptl. Clin. Pharmacol., 8, 147-150 (1986)

39) Murayama T., Kishi N., Koshiura R., Tagkagi K., Furukawa T., Miyamoto K.-I., Anticancer Res., 12, 1471-1474 (1992).

40) Rohrbach M. S., Kreofsky T. J., Vuk-Pavlovic Z., Lauque D., "Plant Polyphenols: Synthesis, Properties, Significance," ed. by Hemingway R. W., Laks P. E., Plenum Press, New York. 1992, pp. 803-824.

41) Radtke O. A., Kiderlen A. F., Kayser O., Kolodziej H., "International Symposium on Immunomodulation by Parasites," Berlin, Germany, Abstract P3, 2001. 